\title{
Safety Assessment of Ethanolic Extract of Padina gymnospora as a Cosmetic Ingredient
}

\author{
Hyun Bon Kang ${ }^{1}$, Jia Bak ${ }^{1}$, Hye Kyung Kim ${ }^{1}$, Yun-Sik Choi ${ }^{1,2,3^{*}}$ \\ ${ }^{1}$ Department of Pharmacy, Kyungsung University, Busan, Korea \\ ${ }^{2}$ Department of Cosmetic Science, Kyungsung University, Busan, Korea \\ ${ }^{3}$ Convergence Research Center for Smart Healthcare, Kyungsung University, Busan, Korea
}

\author{
*Corresponding author: Yun Sik Choi, \\ Department of Pharmacy, Kyungsung \\ University, 309 Suyeong-ro, Nam-gu, Busan \\ 48434, Korea \\ Tel.: +82516634890 \\ Fax: +825042483780 \\ Email: tiana@ks.ac.kr
}

Received August 25, 2021

Revised December 06, 2021

Accepted December 07, 2021

Published December 30, 2021

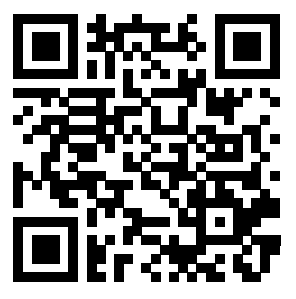

\begin{abstract}
Purpose: In a previous study, we identified the skin-whitening effect of the ethanolic extract of Padina gymnospora. The present study was performed to confirm the safety of the extract in animal replacement tests. Methods: To evaluate the safety of the extract of Padina gymnospora, the photosensitivity test (Harber test), in vitro 3T3 neutral red uptake (3T3 NRU) phototoxicity test, local lymph node assay (5-bromo2'-deoxyuridine enzyme-linked immunosorbent assay), acute oral toxicity test, and reconstructed human epidermis (RHE) test were used. All experiments followed the guidelines of the Korean Ministry of Food and Drug Safety and were conducted by a GLP-certified organization (Chemon Inc.). Results: The extract of Padina gymnospora was not photosensitive: 0\% photosensitization was detected (I grade: very weak). In the 3T3 NRU phototoxicity test, the relative viability of the extract-treated cells was higher than the guideline level; thus, the extract was classified as non-phototoxic. Treatment with the extract did not trigger skin irritation in the RHE test model and did not cause skin sensitization in the local lymph node assay. Finally, oral administration of the extract to rats indicated that it was not a harmful material as the LD50 was estimated at $>2,000 \mathrm{mg} / \mathrm{kg}$. Conclusion: The ethanolic extract of Padina gymnospora was demonstrated to be safe when applied to the skin. Taken together with our previous study of its efficacy, we conclude that this extract has the potential for use as a cosmetic ingredient.
\end{abstract}

Keywords: Animal replacement test, Cosmetic ingredient, Padina gymnospora, Safety, Seaweed

\section{Introduction}

아롱부챗말(Padina gymnospora)은 갈조식물로 그물바탕말과에 속하며 대서양, 태평양, 인도양에 서식하고 우리나라에서는 부산, 거 제도, 제주도 등지에서 분포한다고 알려져 있다. 껍질은 두꺼운 혁질 이며 전체적으로 부채모양이고 몸은 편평하고 가장자리로 갈수록 물 결모양이다. 가운데 부분은 6 겹 정도이며 포자낭 생성 부위는 색이 짙고 10 겹으로 두껍게 되어있다. 크기는 6-7 cm정도이며 크게 자 라는 것은 $30 \mathrm{~cm}$ 까지 자란다(Lee, 2008; Kim \& Boo, 2010). 아롱 부챗말 유래 다당류는 면역반응을 증강시키고 heterofucan은 혈소판 응집을 억제한다(Rajendran et al., 2016; Silva et al., 2005). 또한 아롱부챗말은 피부창상 회복에 효과를 가지는 것으로 보고되었으며
분리된 유효성분들은 미토콘드리아의 기능 이상 완화, 항산화 및 항 염증 효과를 가지는 것으로 알려졌다(Baliano et al., 2016; Marques et al., 2012; Vasantharaja et al., 2019).

최근 들어 식물 추출물을 함유하는 천연화장품에 대한 관심이 증 가하고 있어 육상 및 해양 유래 천연물에 관한 연구가 활발하다. 화 장품 소재로 사용하기 위한 식물 추출물은 열수 또는 에탄올을 이 용한 추출물, 줄기세포를 포함한 식물 세포 배양액, 식물-유래 아 미노산 등 매우 다양하다(Krasteva et al., 2020; Eibl et al., 2018; Trehan et al., 2017; Burnett et al., 2014). 본 연구진은 이전 연 구에서 피부세포를 이용하여 아롱부챗말 추출물의 미백 효능을 검 증하였다. 그 결과 아롱부챗말 추출물은 tyrosinase의 활성을 용 량 의존적으로 억제하였고, $\alpha$-melanocyte-stimulating hormone 
$(\alpha-\mathrm{MSH})$ 에 의한 tyrosinase related protein (TRP)-1, TRP-2 $\mathrm{mRNA}$ 발현도 유의하게 저해함이 확인되었다(Kim et al., 2020). Tyrosinase는 L-tyrosine을 dopaquinone으로 전환시키는 효소 로 멜라닌 합성에 있어 가장 중요한 효소이다(Park et al., 2019), 생성된 dopaquinone은 유멜라닌(eumelanin) 또는 페오멜라닌 (pheomelanin) 합성 경로의 기질로 작용하는데 TRP-1과 TRP-2 는 유멜라닌 합성에 중대한 효소로 tyrosinase와 함께 멜라닌 합성 에 필수적인 효소이다(Lin \& Fisher, 2007; Shim, 2019). 주목할 점으로 $0.5 \%$ 아롱부챗말 추출물은 현재 미백 고시원료로 사용중인 $\operatorname{arbutin}(200 \mu \mathrm{M})$ 대비 멜라닌 합성을 통계적으로 유의하게 감소시겼 다. 따라서 아롱부챗말 추출물은 미백화장품 개발을 위한 천연 원료 로 매우 유용하다고 할 수 있다.

화장품은 전 연령이 장기간 지속적으로 사용하는 제품이므로 화장 품 원료에 대한 안전성은 매우 중요한 이슈이다. 최근 발표된 자료에 따르면 국제화장품일반명(International Nomenclature of Cosmetic Ingredients, INCI)에 등록된 1,358종의 화장품 천연소재(natural substance) 중 56\%가 유해화학물질(hazardous chemical)로 분류되 었다. 이 중 $35 \%$ 는 피부나 눈에, 그리고 $21 \%$ 는 환경에 위해한 것으 로 나타났다. 특히 53 종의 천연소재는 발암성, 유전독성, 생식독성이 있는 것으로 보고되었다(Klaschka, 2015). 이러한 현실을 반영하여 전 세계적으로 화장품 소재의 안전성에 대한 규제가 강화되고 있는 추세이며, 우리나라에서도 화장품 소재의 인체 적용을 위해서는 비 임상시험을 수행해 안전성을 입증해야한다(Lee, 2008). 비임상시험 은 사람에게 미칠 수 있는 영향들을 조사하기 위해 동물, 식물 또는 미생물에게 시험물질을 적용하여 실시하는 시험을 의미하며 비임상 시험관리기준(good laboratory practice, GLP)에 의해 관리된다(Lee et al., 2007; Lee et al., 2016; Yu \& Lee, 2002). 화장품 법에 따라 아롱부챗말 추출물을 포함하는 화장품을 기능성 화장품으로 심사받 기 위해서는 식약청에서 고시하고 있는 비임상시험관리기준 중 "기 능성화장품 심사에 관한 규정"에 맞게 시험이 진행되어야 한다(Cho et al., 2019; Kim et al., 2004, Lee et al., 2011). 따라서, 본 연구 에서는 기능성화장품 심사에 관한 규정에서 요구하는 안전성 자료 중 아롱부챗말 추출물의 광감작성, 광독성, 경구독성, 피부감작성, 1 차 피부자극 시험을 진행하였다. 이를 위하여 모든 실험은 GLP인증기 관인 (주)켐온 비임상연구소에 의뢰하여 진행하였다.

\section{Methods}

본 시험은 GLP인증기관 (주)켐온 비임상연구소에 의뢰하여 진행되 었다.

\section{1. 천연물 추출}

제주 소재의 만타스마린랩에 의뢰하여 아롱부챗말의 채취와 동정
을 진행하였다. 채취한 아롱부챗말을 세척과 건조한 후 $2.32 \mathrm{~kg}$ 의 아 롱부챗말을 잘게 분쇄하고 주정 에탄올에 넣어 $24 \mathrm{~h}$ 동안 실온에서 침출추출을 2 회 진행한 후 감압 농축기(A-1000S; EYELA, Japan) 로 농축하여 진공동결건조기(FD5512, 일신, 대한민국)로 동결건조하 여 추출분말 $98.435 \mathrm{~g}$ 을 얻음(수득률 $4.24 \%$ ).

\section{2. 시험계}

1) 실험동물

광감작성 시험은 기니피그(Hartley, 수컷, (주)샘타고 바이오코 리아, 한국)를 이용하였고 사료는 기니피그용 고형사료(altromin spezialfutter $\mathrm{GmbH} \& \mathrm{Co} . \mathrm{KG}$, Germany)를 자유섭취 하도록 하 였다. 국소림프절 시험은 마우스(CBA/J, 암컷, 코아텍, 대한미국), 경구독성 시험은 랫드(Sprague-Dawley, 암컷, (주)오리엔트 바이 오, 대한미국)로 진행하였고 랫드와 마우스 사료는 Teklad certified irradiated global 18\% protein rodent diet (Envigo, UK)로 자유섭취 하도록 하였다. 모든 동물은 온도 $\left(22 \pm 3^{\circ} \mathrm{C}\right)$, 습도 $\left(55 \pm 15^{\circ} \mathrm{C}\right)$, 환기횟 수(10-20 회/h), 조명시간 $12 \mathrm{~h}$ (오전 8시-오후 8시) 및 조도(150$300 \mathrm{Lux}$ ) 조건에서 사육하였다. 본 시험은 (주) 켐온 비임상연구 실험 동물운영위원회에 의해 승인되었다(심의번호: 20-G410, 20-M536, 20-R335).

2) 체중

기니피그는 투여개시일(투여 전), 그 이후에는 주 1 회 및 최종평가 일에 체중을 측정하였다. 마우스는 시료 도포 시작일과 부검전에 측 정하였다. 랫드는 투여전, $2,4,8$ 및 15 일에 측정하였다.

\section{3) 조직 및 세포 배양}

(1) BALB/3T3 clone A31

광독성 시험에서 사용한 BALB/3T3 clone A31 (3T3 cell, ATCC, USA)는 Dulbecco's Modified Eagle's Medium (DMEM, Gibco, USA) 에 $1 \%$ penicillin-streptomycin(P/S, Gibco)과 $10 \%$ fetal bovine serum (FBS, Gibco)를 첨가한 배지에 $5 \%$ 의 이산화탄소와 포화수증 기를 함유한 $37 \pm 1^{\circ} \mathrm{C}$ 의 조건으로 항온배양기에서 배양되었다. 이 세 포주는 광독성시험에 널리 사용되고 있으며, 본 시험에 적합함이 입 증되었다(Spielmann et al., 1998a; Spielmann et al., 1998b).

(2) 림프절 배양

국소림프절 시험에서는 투여 6 일 후 $\mathrm{CO}_{2}$ 로 흡입 마취시켜 안락사 한 동물의 양쪽 귀에서 림프절을 적출하여 cell strainer를 이용하여 단일세포가 되게 하여 사용하였다.

\section{(3) $\mathrm{RHE}$ 조직}

피부자극 시험에서 사용한 RHE 조직(MatTek, USA)은 DMEM을 포함한 EpiDerm Assay medium (MatTek)에서 $5 \% \mathrm{CO}_{2}$, 포화 수증 
기를 함유한 $37 \pm 1^{\circ} \mathrm{C}$ 조건으로 항온배양기(3111; Forma, USA)에서 배양되었다. 시험 전 조직을 상온에서 안정화시켜야 하며 $1 \mathrm{~h}$ 동안 전 배양을 하였다.

\section{3. 광감작성 시험: photosensitivity test (Harber test) \\ 1) 투여}

아롱부챗말 추출물 동결건조 분말에 대하여 Hartley계 기니픽에 서 광감작성 반응을 평가하였다. 부형제대조군(dimethyl sulfoxide, $\mathrm{DMSO}$, Sigma-Aldrich, USA), 시험물질군(아롱부챗말 추출물), 양성대조군(3,5,4-tribromosalicylanilide, TBS, Tokyo Chemical industry, Japan)으로 총 3 개의 군으로 각 군의 평균 체중이 균일하게 분포하도록 동물을 무작위로 분배하였다. 예비시험 결과에 따라 아롱 부챗말 추출물은 DMSO에 녹여 최종 $10 \%$ 농도로 투여하였으며, TBS 는 acetone (대정화금, Korea)에 녹여 최종 $2 \%$ 농도로 투여하였다.

2) 측정

(1) 감작

동물의 경배부를 $4 \times 2 \mathrm{~cm}^{2}$ 로 제모한 후 $\mathrm{DMSO}$, 아롱부챗말 추출 물 혹은 TBS $0.1 \mathrm{~mL}$ 를 제모 부위 전체에 걸쳐 고르게 도포하고 30 $\min$ 후 동물을 고정틀에 넣어 UVA $(305-420 \mathrm{~nm})$ 를 $30 \mathrm{~J} / \mathrm{cm}^{2}$ 로 조 사하였다. 이 과정을 1 일 1 회, 3 일 간격으로 총 3 회 반복 실시하였 다.

\section{(2) 야기}

광감작 개시일로부터 4 주 후 동물의 하배부 $1.5 \times 1.5 \mathrm{~cm}$ 정사각 형으로 제모하였다. 투여 부위를 2 구획으로 나누어 DMSO, 아롱부 챗말 추출물 혹은 TBS $0.02 \mathrm{~mL}$ 를 도포하였다. 척추를 중심으로 오 른쪽은 알루미늄 호일로 감싸서 자외선 조사를 차단하고 왼쪽은 UVA (305-420 nm)를 $9 \mathrm{~J} / \mathrm{cm}^{2}$ 로 조사하였다. 광야기 종류 후 24,48 및 $72 \mathrm{~h}$ 째 적용부위의 홍반과 가피 및 부종의 상태를 관찰하여 Draize 평가기준에 따라 판정하였다(Draize, 1944).

\section{4. 광독성시험: $3 T 3 \mathrm{NRU}$ phototoxicity test}

1) 투여

아롱부챗말 추출물 동결건조 분말의 자외선 노출 후 유도되는 잠 재적 광독성 을 평가하기 위해 화장품 광독성 동물대체시험법 가이 드라인(In vitro 3T3 NRU 광독성시험)을 참고하여 진행하였다. 아롱 부챗말을 $1 \mathrm{mg} / \mathrm{mL}$ 농도가 되도록 $\mathrm{DMSO}$ 를 녹여 제조하였고 양성 대조물질은(chloropromzaine hydrochloride, CPZ; Sigma-Aldrich) $\mathrm{DMSO}$ 에 최고 농도의 100 배가 되도록 용해하여 제조한 뒤 Hank's balanced salt solution (HBSS, Gibco)에 100 배 희석하여 처리하였 다. 예비시험을 통해 아롱부챗말 추출물의 최고 농도를 $1000 \mu \mathrm{g} / \mathrm{mL}$ 로 결정하였고 총 8 단계 농도군으로(0, 7.8, 15.6, 31.3, 62.5, 125 , $250,500,1000 \mu \mathrm{g} / \mathrm{mL}$ )나누어 자외선 비조사와 조사 군으로 구성 하였다. 양성대조군은 비조사군 $(0,0.8,1.56,3.1,6.25,12.5,25$,
$50,100 \mu \mathrm{g} / \mathrm{mL})$, 조사군 $(0,0.049,0.098,0.195,0.39,0.78,1.56$, $3.13,6.25 \mu \mathrm{g} / \mathrm{mL}$ )으로 진행하였다.

2) 측정

96 well plate에 $1 \times 10^{4} /$ well로 분주하여 $24 \mathrm{~h}$ 동안 배양하였다. 아롱부챗말 추출물을 각 농도 당 6 개의 well에 $100 \mu \mathrm{L}$ 씩 처리하였다. 약 $1 \mathrm{~h}$ 후 UV조사군과 UV비조사군을 자외선 조사 장치(Bio spectra, Vilber Lourmat, France)에 광원으로부터 약 $25 \mathrm{~cm}$ 떨어진 거리에 두고, UV비조사군은 aluminum foil을 사용하여 자외선 조사를 차단 하였다. 광세기가 약 $1.7 \mathrm{~mW} / \mathrm{cm}^{2}$ 가 되도록 하였고, 광조사량은 $5 \mathrm{~J} /$ $\mathrm{cm}^{2}$ 로 설정하였고 광노출시간은 약 $50 \mathrm{~min}$ 이었다. 자외선 조사 후 HBSS로 세척하여, 새로운 배양액에 18-22 h 배양하였다. 배양한 세 포에서의 세포 생존율(cell viability) 측정을 위해 각 well당 Neutral Red Medium $100 \mu \mathrm{L}$ 를 넣고, 약 $3 \mathrm{~h}$ 동안 배양 후 생성된 formation 을 extraction buffer로 유출한 후 $1 \mathrm{~h}$ 이내 $540 \mathrm{~nm}$ 에서 흡광도를 측정하였다. 시험결과 PIF 값이 5 를 초과하거나 mean photo effect (MPE) 값이 0.15 를 초과하면 광독성이 있음으로 판정한다.

\section{5. 피부감작성 시험: local lymph node assay: BrdU-ELISA \\ 1) 투여}

아롱부챗말 추출물 동결건조 분말 도포 후 나타나는 림프절 내 림 프세포 증식을 측정하여 피부감작성 평가를 진행하였고 화장품 독성 시험 동물대체시험법[ELISA법을 이용한 국소림프절 시험] 가이드라 인을 참고하였다. 음성대조군(DMSO), 시험물질군(아롱부챗말 추출 물 $12.5 \%, 25 \%, 50 \%$ 농도), 양성대조군( $\alpha$-hexylcinnamaldehyde, HCA; Tokyo Chemical industry, Japan)으로 총 5개의 군으로 각 군 의 평균 체중이 균일하게 분포하도록 동물을 무작위로 분배하였다. 예비시험 결과에 따라 아롱부챗말 추출물을 $\mathrm{DMSO}$ 에 현탁하여 도포 농도를 $50 \%$ 이하로 설정하였으며 양성대조물질로는 $\mathrm{HCA}$ 를 사용하 였고 25\% 농도의 acetone과 olive oil (Sigma-Aldrich)를 4:1 비율로 혼합하여 만든 $\mathrm{AOO}$ 에 용해하여 조제하였다. 표지물질인 5-bromo2'-deoxyuridine (BrdU; Sigma-Aldrich)는 생리식염수(대한약품공 업, 한국)에 용해하여 $10 \mathrm{mg} / \mathrm{mL}$ 로 조제하였다. 아롱부챗말 추출물 을 농도별로 양쪽 귀배측에 약 10-15 $\mu \mathrm{L}$ 씩 1 회 도포 후 $30 \mathrm{~min}$ 이 내 2 회 도포하여 하루에 $25 \mu \mathrm{L}$ 씩, 1 회, 3 일간 도포하였다. $\mathrm{BrdU}$ 는 $0.5 \mathrm{~mL}$ (5 mg/head)씩 1일, 1 회, 시험물질 최종 도포일로부터 5 일 째에 복강투여 하였다.

\section{2) 관찰 및 측정}

피부감작 평가를 위해 귀 두께, 귀 및 림프절 중량 및 피부반응, 세 포증식변화를 측정하였다. 물질 도포 전, 도포 $48 \mathrm{~h}$ 후 그리고 부검 전에 캘리퍼스를 이용하여 귀 가장자리로부터 약 $1 \mathrm{~mm}$ 안쪽에서 양 쪽 귀의 두께를 3 회 반복하여 측정하였다. 안락사한 동물의 양쪽 귀 를 관찰하여 피부반응을 점수화 하였으며 림프절을 적출하여 양쪽 
귀 및 림프절의 중량을 각각 측정하였다. 세포증식측정은 $\mathrm{BrdU}$ kit (Roche, USA)를 사용하였다. 림프절 단일 세포 현탁액을 Dulbecco's phosphate buffered saline (DPBS, Gibco)로 15 배 희석한 다음 96 well microplate에 $100 \mu \mathrm{L}$ 씩 분주였다. 이후 원심분리하여 상층액을 제거하고 건조시킨 후 FixDenat solution을 넣고 실온에서 $30 \mathrm{~min}$ 간 배양한 뒤 anti-BrdU-POD working solution을 $100 \mu \mathrm{L}$ 넣어 실온 에서 60-90 $\mathrm{min}$ 간 배양했다. 세척 후 substrate solution을 각 well당 $100 \mu \mathrm{L}$ 넣은 후 차광하여 $370 \mathrm{~nm}$ 와 $492 \mathrm{~nm}$ (reference)에서 흡광도 를 측정하였다. Blank는 DPBS를 $100 \mu \mathrm{L}$ 씩 분주하였다.

BrdU Labeling Index=(ABS $\left.370-\mathrm{ABS}_{\text {blank } 370}\right)-\left(\mathrm{ABS}_{492}-\mathrm{ABS}_{\text {blank } 492}\right)$

평균자극지수(stimulation index, $\mathrm{SI})$ 는 시험군의 평균 $\mathrm{BrdU}$ labeling index에서 음성대조군의 평균 BrdU labeling index로 나눠 준 값이다.

$\mathrm{SI}=($ 시험군의 평균 $\mathrm{BrdU}$ labeling index)/(음성대조군의 평균 BrdU labeling index)

$\mathrm{SI} \geq 1.6$ 이면 피부감작성이 있는 물질로 판정하였다.

\section{6. 급성경구독성 시험: acute oral toxicity test}

1) 투여

아롱부챗말 추출물 동결건조 분말의 독성을 확인하기 아롱부챗말 추 출물을 $\mathrm{DMSO}$ 에 녹여 화장품 단회투여독성 동물대체시험법[독성등급 법] 가이드라인(안내서-0867-01) 및 $\mathrm{OECD}$ 가이드라인(TG423)를 참 고하여 급성 경구투여를 진행하였다. 투여군은 시험물질(아롱부챗말 추 출물)단일 투여로 농도에 따라 G1 (300 mg/kg), G2 (300 mg/kg), G3 $(2000 \mathrm{mg} / \mathrm{kg}), \mathrm{G} 4(2000 \mathrm{mg} / \mathrm{kg})$ 으로 평균 체중이 균일하게 분포되도 록 동물을 무작위로 분배하였다.

독성등급에 따라 $300 \mathrm{mg} / \mathrm{kg}$ 두 단계와 $2000 \mathrm{mg} / \mathrm{kg}$ 두 단계로 각 단계별 암컷 3 마리씩 순차적으로 투여하였다. 시험 하루 전에 금식하 여 위 내용물을 비운 후 1 일, 1 회, 단회투여 하였고 투여 종료 3-4h 이후 사료를 재급여 하였다.

\section{2) 관찰 및 측정}

투여 15 일 후까지 사망률, 체중변화 및 일반증상 관찰하였고, 15 일 후에는 흡입 마취시킨 후 개복하여 후대정맥 및 복대정맥을 절단하는 방법으로 방혈 치사시켜 육안적으로 모든 장기를 관찰하였다.

\section{7. 피부자극 시험: reconstructed human epidermis test}

1) 투여

아롱부챗말 추출물 동결건조 분말의 피부에 대한 자극성 평가를 화 장품 광독성 동물대체시험법[인체피부모델을 이용한 피부자극시험 법]에 따라 진행하였다. 음성대조군(DMSO), 양성대조군(5\% sodium dodecyl sulfate, SDS; MatTek, USA), 시험물질군(아롱부챗말 추출물) 으로 총 3 개 군이며 물질당 3 개의 조직을 사용하였다. MatTek사에서 제공한 RHE 조직에 assay medium $0.9 \mathrm{~mL}$ 와 아롱부챗말 추출물 25 $\mathrm{mg}$, 음성 및 양성대조군은 $30 \mu \mathrm{L}$ 씩 도포하여 $35 \mathrm{~min}$ 간 표준배양조건 에서 배양하였다. 배양 후 실온에서 $25 \mathrm{~min}$ 간 배양하였다. $60 \mathrm{~min}$ 배 양 후 조직을 세척한 후 새로운 6 well plate에 표준배양조건에서 후배 양 하였다.

2) 측정

3-(4,5-Dimethylthiazol-2-yl)-2,5-diphenyltetrazolium bromide (MTT)를 $1 \mathrm{mg} / \mathrm{mL}$ 의 농도로 만든 후 24 well plate에 $300 \mu \mathrm{L}$ 씩 분주하 여 후배양이 끝난 조직을 넣고 $3 \mathrm{~h}$ 동안 표준배양조건에서 차광하여 배 양하였다. $2 \mathrm{~mL}$ 의 Isopropanol을 넣은 새로운 24 well plate에 MTT 반 응이 끝난 조직을 옮긴 후 sealing하여 $2 \mathrm{~h}$ 동안 상온에서 shaking하 여 formazan을 추출하였다. 추출이 끝나면 96 well plate에 조직당 2 개 well에 각각 $200 \mu \mathrm{L}$ 씩 넣고 $570 \mathrm{~nm}$ 의 파장에서 흡광도를 측정하였다. Blank는 isopropanol을 동일하게 처리하였다. 발색성 보정을 위한 살아 있는 조직과 비특이적인 색에 대한 보정을 위하여 MTT용액 대신 배지 를 넣어 주었다. DMSO 도포 군의 조직생존율을 $100 \%$ 로 하고 조직생 존율이 $50 \%$ 초과인 경우는 비자극 물질로, $50 \%$ 이하인 경우는 자극물 질로 판정하였다.

보정한 조직생존율(\%)=시험물질평균 조직생존율-발색성 대조군의 평균조직생존율-MTT 환원성 대조군 평균 조직생존율+비특이적 색 에 대한 대조군의 평균조직생존율

\section{8. 통계 분석}

시험 결과 통계분석은 SPSS statistics 22 for medical science (SPSS $\mathrm{Inc}, \mathrm{USA})$ 프로그램을 사용하였다. 유의수준은 $p<0.05$ 로 설정하였으며 일원분산분석을 적용하였고 분산의 동질성은 Levene test로 검정하였 다. Duncan 및 Dunnett T3으로 사후분석을 실시하였다. 용량상관성은 카이제곱 검정의 선형 대 선형결합으로 검정하였다. 음성 및 양성군간 평균의 차이는 Student $t$-test로 분석하였다.

\section{Results and Discussion}

\section{1. 광감작성 시험: photosensitivity test (harber test)}

자외선에 지속적으로 노출되다 보면 홍반증상에서부터 시작해서 심하게는 유전자의 손상이 발생해 피부암을 유발하게 되므로 광에 의 해 화장품이 영향을 받을 가능성이 있는지 확인해야 한다(Grosjean \& Sarasin, 2005). 따라서 광감작성 및 광독성 시험을 진행해야 하며 설치 류 등에는 피부암이 유발될 수 있고 일반적으로 토끼, 기니픽 등의 동물 로 실험한다(Wiemann et al., 2001). 광감작성 시험에 따르면 양성대조 군에서는 30-32일 후에 발적이 관찰된 반면 아롱부챗말 추출물 도포군 은 일반증상 및 체중변화의 이상의 관찰되지 않았다. 음성대조군 및 아 롱부챗말 추출물 도포군의 경우 광야기 종료 후 24,48 및 78 시간에 자 외선 조사 및 차단부위에서 아무런 반응이 나타나지 않아서 $0 \%$ 광감작 
율로 매우약함( I 등급)으로 평가하였다. 반면에 양성대조군은 광야기 종료 24,48 및 $72 \mathrm{~h}$ 후에 모든 개체의 자외선 조사 부위에서 경도의 홍 반 혹은 뚜렷한 홍반이 관찰되어 $100 \%$ 광감작율로 매우강함( $\mathrm{V}$ 등급)으 로 평가하였다(Table 1).

본 시험은 시험물질 아롱부챗말 추출물에 대하여 기니픽에서 광감작 성 반응을 평가하기 위하여 수행하였고 본 시험은 모든 타당성 기준을 만족하였다. 시험결과에 따르면 아롱부챗말 추출물의 광감작율은 $10 \%$ 농도에서 광감작성이 없는 것으로 평가하였다.

\section{2. 광독성 시험: $3 T 3 \mathrm{NRU}$ phototoxicity test}

유럽에서부터 시작된 동물보호 운동으로 암을 유발할 수 있는 광독 성 시험은 동물을 대신해서 3T3 cell을 이용한 대체시험법으로 진행 하도록 개정되었다(Kim et al., 2015). 마우스 embryo의 fibroblast인
3T3 cell에 자외선을 조사하거나 하거나 또는 하지 않은 세포를 neutral red uptake (NRU)로 염색하여 그 흡광도의 차이를 비교하여 독성을 평 가하는 방법이다(Lee et al., 2005).

시험 결과에 따르면 아롱부챗말 추출물을 처리한 세포의 $\mathrm{IC}_{50}$ 은 자외 선 비조사시에 $1000 \mu \mathrm{g} / \mathrm{mL}$, 자외선 조사시에는 약 $663.4 \mu \mathrm{g} / \mathrm{mL}$ 이였 으며 $\mathrm{PIF}$ 는 1.51 이며, $\mathrm{MPE}$ 는 -0.006 이였다. 양성대조물질인 $\mathrm{CPZ}$ 의 $\mathrm{IC}_{50}$ 은 자외선 비조사시에는 $28.07 \mu \mathrm{g} / \mathrm{mL}$, 자외선 조사시에는 1.593 $\mu \mathrm{g} / \mathrm{mL}$ 이였다. $\mathrm{PFF}$ 및 $\mathrm{MPE}$ 는 각각 17.63 및 0.352 이였다(Table 2). 아롱부챗말 추출물을 처리한 세포 생존율은 자외선 비조사 및 조사 순 으로 각각 94.32-103.23\% 및 4.81-110.18\% 였다(Table 3). CPZ의 세포 생존율은 자외선 비조사 및 조사 순으로 0.97-98.47\% 및 3.50$99.51 \%$ 였다(Table 4).

본 시험은 시험물질 아롱부챗말 추출물의 광독성 $3 \mathrm{~T} 3$ 세포에 자외

Table 1. Evaluation of skin reaction in guinea pigs

\begin{tabular}{|c|c|c|c|c|c|c|c|c|c|c|c|c|c|c|c|c|c|c|}
\hline \multicolumn{19}{|c|}{ Evaluation of skin reaction (Ery) } \\
\hline Condition & \multicolumn{9}{|c|}{ UV (-) } & \multicolumn{9}{|c|}{ UV (+) } \\
\hline Group & & G1 & & & G2 & & & G3 & & & G1 & & & G2 & & & G3 & \\
\hline Hours after treatment & 24 & 48 & 72 & 24 & 48 & 72 & 24 & 48 & 72 & 24 & 48 & 72 & 24 & 48 & 72 & 24 & 48 & 72 \\
\hline$\sum$ Score & 0 & 0 & 0 & 0 & 0 & 0 & 0 & 0 & 0 & 0 & 0 & 0 & 0 & 0 & 0 & 0 & 0 & 0 \\
\hline Mean Score & 0 & 0 & 0 & 0 & 0 & 0 & 0 & 0 & 0 & 0 & 0 & 0 & 0 & 0 & 0 & 0 & 0 & 0 \\
\hline Sensitization rate (\%) & 0 & 0 & 0 & 0 & 0 & 0 & 0 & 0 & 0 & 0 & 0 & 0 & 0 & 0 & 0 & 0 & 0 & 0 \\
\hline
\end{tabular}

G1, vehicle control; G2, test article; G3, positive control; Ery, erythema and eschar.

Mean score $=$ Sum of scores/No. of animals

Sensitization rate $=($ No. of positive animals $/$ No. of animals $) \times 100$

Table 2. Calculated IC ${ }_{50}$, PIE and MPE values in $3 T 3$ cells

\begin{tabular}{|c|c|c|c|c|}
\hline \multirow{2}{*}{$\begin{array}{l}\text { Test articles and } \\
\text { positive control article }\end{array}$} & \multicolumn{2}{|c|}{$\mathrm{IC}_{50}(\mu \mathrm{g} / \mathrm{mL})$} & \multirow{2}{*}{ PIE } & \multirow{2}{*}{ MPE } \\
\hline & UV (-Irr) & UV (+Irr) & & \\
\hline Padina gymnospora & $>1000$ & 663.4 & $>1.51$ & -0.006 \\
\hline $\begin{array}{l}\text { Chloropromazine } \\
\text { hydrochloride }\end{array}$ & 28.07 & 1.593 & $>17.63$ & 0.352 \\
\hline
\end{tabular}

$\mathrm{IC}_{50}$, 50\% inhibitory concentration; PIE, photo irradiation factor; MPE, mean photo effect.

Table 3. Results of cell viability tests in article-treated cells

\begin{tabular}{|c|c|c|c|}
\hline \multicolumn{2}{|c|}{ UV (-Irr) } & \multicolumn{2}{|c|}{ UV (+Irr) } \\
\hline Dose $(\mu \mathrm{g} / \mathrm{mL})$ & $\%$ Cell viability & Dose $(\mu \mathrm{g} / \mathrm{mL})$ & $\%$ Cell viability \\
\hline 0 & 100.00 & 0 & 100.00 \\
\hline 7.8 & 94.79 & 7.8 & 109.52 \\
\hline 15.6 & 94.32 & 15.6 & 108.67 \\
\hline 31.3 & 95.63 & 31.3 & 110.18 \\
\hline 62.5 & 96.84 & 62.5 & 104.75 \\
\hline 125 & 103.23 & 125 & 107.66 \\
\hline 250 & 97.54 & 250 & 99.55 \\
\hline 500 & 101.92 & 500 & 78.97 \\
\hline 1000 & 96.68 & 1000 & 4.81 \\
\hline
\end{tabular}

Test article : Padina gymnospora. 
선 노출 후 유도되는 독성을 지표로 하여 평가하기 위하여 실시하였으 며, 시험의 타당성 조건을 모두 만족하였다. 본 시험에 적용한 농도범 위 내에서, 광독성을 평가한 결과 아롱부챗말 추출물은 광자극지수 및 평균광효과 모두에서 광독성 없음을 나타내었다.

\section{3. 피부감작성 시험: local lymph node assay: BrdU ELISA}

피부에 화장품을 바른 후 접촉성 피부염으로 인해 항원·항체반응이 일어날 수 있기 때문에 피부 감작성 시험을 진행해야 한다. 역시 실험동
물을 이용하는 것을 지향하려 local node assay (LNNA)와 같은 대체 시 험이 소개되었는데 이는 마우스 귀에 시험물질을 도포한 뒤 방사성 동 위원소를 이용하여 림프절 증식반응을 통해 감작성을 확인하는 것이다 (Heo et al., 2019, Basketter et al., 1996). 하지만 방사선 동위원소는 취급이 까다롭기 때문에 새로운 대체법으로 BrdU ELISA를 이용한 방 법이 소개되었는데 $\mathrm{BrdU}$ 를 부검 전에 미리 투여한 뒤 림프절을 단일 세 포로 추출해 $\mathrm{BrdU}$ 발색 조건에 따라 처리 후 흡광도를 측정하여 평균자 극지수를 구하는 방법이다(Lee et al., 2003).

Table 4. Results of cell viability tests in positive control- treated cells

\begin{tabular}{|c|c|c|c|}
\hline \multicolumn{2}{|c|}{ UV (-Irr) } & \multicolumn{2}{|c|}{ UV (+Irr) } \\
\hline Dose $(\mu \mathrm{g} / \mathrm{mL})$ & $\%$ Cell viability & Dose $(\mu \mathrm{g} / \mathrm{mL})$ & $\%$ Cell viability \\
\hline 0 & 100.00 & 0 & 100.00 \\
\hline 0.78 & 97.76 & 0.049 & 99.51 \\
\hline 1.56 & 98.47 & 0.098 & 94.65 \\
\hline 3.13 & 97.57 & 0.195 & 96.91 \\
\hline 6.25 & 98.31 & 0.39 & 94.58 \\
\hline 12.5 & 92.90 & 0.78 & 81.94 \\
\hline 25 & 62.69 & 1.56 & 53.91 \\
\hline 50 & 3.07 & 3.13 & 5.08 \\
\hline 100 & 0.97 & 6.25 & 3.50 \\
\hline
\end{tabular}

Positive control: chlolopromazine hydrochloride.

Table 5. Results of ear thickness tests in mouse

\begin{tabular}{|c|c|c|c|c|c|c|}
\hline \multirow{3}{*}{ Dose (\%) } & \multicolumn{6}{|c|}{ Ear thickness (mm, Mean \pm SD) } \\
\hline & \multicolumn{2}{|c|}{ Day 1} & \multicolumn{2}{|c|}{ Day 3} & \multicolumn{2}{|c|}{ Day 6} \\
\hline & Left & Right & Left & Right & Left & Right \\
\hline 0 & $0.155 \pm 0.007$ & $0.155 \pm 0.006$ & $0.153 \pm 0.010$ & $0.151 \pm 0.007$ & $0.152 \pm 0.004$ & $0.154 \pm 0.004$ \\
\hline 12.5 & $0.154 \pm 0.010$ & $0.157 \pm 0.004$ & $0.153 \pm 0.006$ & $0.153 \pm 0.005$ & $0.153 \pm 0.003$ & $0.152 \pm 0.006$ \\
\hline 25 & $0.153 \pm 0.007$ & $0.153 \pm 0.005$ & $0.151 \pm 0.006$ & $0.150 \pm 0.003$ & $0.157 \pm 0.007$ & $0.153 \pm 0.004$ \\
\hline 50 & $0.147 \pm 0.006$ & $0.148 \pm 0.007$ & $0.165 \pm 0.005^{* *}$ & $0.166 \pm 0.003$ & $0.155 \pm 0.004$ & $0.149 \pm 0.005$ \\
\hline HCA 25 & $0.157 \pm 0.008$ & $0.156 \pm 0.010$ & $0.157 \pm 0.007$ & $0.157 \pm 0.006$ & $0.149 \pm 0.002$ & $0.151 \pm 0.001$ \\
\hline
\end{tabular}

Vehicle: DMSO (dimethyl sulfoxide), Positive control: HCA ( $\alpha$-hexylcinnamaldehyde).

DMSO, Padina gymnospora, and HCA were applied to the dorsum of both ears daily for three consecutive days.

${ }^{* *}$ Significantly different from the negative control group at $p<0.01$.

Table 6. Results of ear and absolute auricular lymph node weights in mouse post administration of Padina gymnospora and HCA

\begin{tabular}{lcc}
\hline Dose (\%) & Ear $(\mathrm{g}$, Mean \pm SD) & Auricular lymph node (g, Mean \pm SD) \\
0 & $0.0185 \pm 0.0006$ & $0.0036 \pm 0.0009$ \\
12.5 & $0.0187 \pm 0.0010$ & $0.0052 \pm 0.0005^{* *}$ \\
25 & $0.0179 \pm 0.0006$ & $0.0047 \pm 0.0010^{*}$ \\
50 & $0.0188 \pm 0.0012$ & $0.0047 \pm 0.0003^{*}$ \\
HCA 25 & $0.0203 \pm 0.0003^{* *}$ & $0.0112 \pm 0.0027^{* *}$ \\
\hline
\end{tabular}

Vehicle: DMSO (Dimethyl sulfoxide); Positive control: HCA ( $\alpha$-hexylcinnamaldehyde).

Vehicles, Padina gymnospora, and HCA were applied to the dorsum of both ears daily for three consecutive days. A pair of auricular lymph nodes from each mouse was excised and weighed. Data represent the sum of both sides of the organs.

*Significantly different from the negative control group at $p<0.05$.

** Significantly different from the negative control group at $p<0.01$. 
1) 귀 두께, 중량 측정

$50 \%$ 아롱부챗말 추출물 도포군은 도포 3 일 후 좌측 귀에서 음성대조군 에 비해 유의한 두께 증가가 있었으나 도포 6 일 후에는 관찰되지 않았다 (Table 5). 아롱부챗말 추출물 도포군에서 음성대조군에 비해 귀 중량은 통 계학적으로 유의한 증가가 관찰되지 않았다. 양성대조군에서는 림프절 및 귀 중량이 음성대조군에 비해 유의하게 증가하였다(Table 6).
2) 피부자극 평가 및 일반증상

아롱부챗말 추출물 도포군에서 통계학적으로 유의한 체중 변화는 없었고 피부자극 평가 점수는 0점으로 홍반은 관찰되지 않았다. 아롱 부챗말 추출물 도포군에서 투여 2 일부터 5 일 후까지 피부의 착색화가 관찰되었다. $25 \%$ 에서는 투여 6 일 후부터 회복되었고 $50 \%$ 에서는 도포 6 일 후 까지도 피모의 착색화가 지속적으로 관찰되었다(Table 7, 8).

Table 7. Erythema scores in mice

\begin{tabular}{lccc}
\hline \multirow{2}{*}{ Dose (\%) } & Animals per Dose & \multicolumn{2}{c}{ Erythema scores (Mean \pm SD) } \\
\cline { 3 - 4 } 0 & 5 & Left & $0.0 \pm 0.00$ \\
12.5 & 5 & $0.0 \pm 0.00$ & $0.0 \pm 0.00$ \\
25 & 5 & $0.0 \pm 0.00$ & $0.0 \pm 0.00$ \\
50 & 5 & $0.0 \pm 0.00$ & $0.0 \pm 0.00$ \\
HCA 25 & 5 & $0.0 \pm 0.00$ & $0.0 \pm 0.00$ \\
\hline
\end{tabular}

Vehicle: DMSO (dimethyl sulfoxide); Positive control: HCA ( $\alpha$-hexylcinnamaldehyde).

Both ears of each mouse were observed for erythema and scored on day 6 .

Table 8. Observations for clinical signs in mice

\begin{tabular}{|c|c|c|c|c|c|c|c|}
\hline No & Animal ID & Day 1 & Day 2 & Day 3 & Day 4 & Day 5 & Day 6 \\
\hline \multirow{5}{*}{0} & 1 & 0 & 0 & 0 & 0 & 0 & 0 \\
\hline & 2 & 0 & 0 & 0 & 0 & 0 & 0 \\
\hline & 3 & 0 & 0 & 0 & 0 & 0 & 0 \\
\hline & 4 & 0 & 0 & 0 & 0 & 0 & 0 \\
\hline & 5 & 0 & 0 & 0 & 0 & 0 & 0 \\
\hline \multirow{5}{*}{12.5} & 6 & 0 & 0 & 0 & 0 & 0 & 0 \\
\hline & 7 & 0 & 0 & 0 & 0 & 0 & 0 \\
\hline & 8 & 0 & 0 & 0 & 0 & 0 & 0 \\
\hline & 9 & 0 & 0 & 0 & 0 & 0 & 0 \\
\hline & 10 & 0 & 0 & 0 & 0 & 0 & 0 \\
\hline \multirow{5}{*}{25} & 11 & 0 & 1 & 1 & 1 & 1 & 0 \\
\hline & 12 & 0 & 1 & 1 & 1 & 1 & 0 \\
\hline & 13 & 0 & 1 & 1 & 1 & 1 & 0 \\
\hline & 14 & 0 & 1 & 1 & 1 & 1 & 0 \\
\hline & 15 & 0 & 1 & 1 & 1 & 1 & 0 \\
\hline \multirow{5}{*}{50} & 16 & 0 & 1 & 1 & 1 & 1 & 1 \\
\hline & 17 & 0 & 1 & 1 & 1 & 1 & 1 \\
\hline & 18 & 0 & 1 & 1 & 1 & 1 & 1 \\
\hline & 19 & 0 & 1 & 1 & 1 & 1 & 1 \\
\hline & 20 & 0 & 1 & 1 & 1 & 1 & 1 \\
\hline \multirow{5}{*}{ HCA 25} & 21 & 0 & 0 & 0 & 0 & 0 & 0 \\
\hline & 22 & 0 & 0 & 0 & 0 & 0 & 0 \\
\hline & 23 & 0 & 0 & 0 & 0 & 0 & 0 \\
\hline & 24 & 0 & 0 & 0 & 0 & 0 & 0 \\
\hline & 25 & 0 & 0 & 0 & 0 & 0 & 0 \\
\hline
\end{tabular}

Vehicle: DMSO (dimethyl sulfoxide); Positive control: HCA ( $\alpha$-hexylcinnamaldehyde)

0 : Normal; 1 : coloring of fur. 


\section{3) 세포증식변화 측정}

음성대조군, 아롱부챗말 추출물 도포군( $12.5,25,50 \%)$, 양성대 조군 순으로 $0.148,0.129,0.191,0.256,0.632$ 의 평균 $\mathrm{BrdU}$ 흡광 도를 가졌다. 평균자극지수는 아롱부챗말 추출물 도포군(12.5, 25 , $50 \%)$, HAS 도포군 순으로 $0.87,1.29,1.72,4.26$ 의 자극지수를 가 졌으며 $12.5,25 \%$ 에서는 유의하게 증가하지 않았으나 $50 \%$ 에서 유의 하게 증가하였다(Table 9).

본 시험은 시험물질인 아롱부챗말 추출물을 도포한 후 나타나는 림프절 내 림프세포 증식을 측정하여 피부감작성을 평가하기 위하 여 실시하였고, 모든 타당성 기준을 만족하였다. 시험 결과에 따르면 $50 \%$ 아롱부챗말 추출물 도포군에서는 피부감작성을 가지지만 $25 \%$ 이하 도포군에서는 피부감작성을 보이지 않는 것으로 판단된다.

\section{4. 경구독성 시험: acute oral toxicity test}

피부에 화장품을 적용 할 때 독성이 없이 안전한지를 평가해야 하 는데 시험 동물의 사망률을 산출한 $\mathrm{LD}_{50}$ (median lethal dosage)를 이용하여 평가해왔다. 최근에는 시험 동물 수와 고통을 줄이고자 고 정 투여량 $(5,50,500,2000 \mathrm{mg} / \mathrm{kg})$ 을 정하고 시작 농도를 $300 \mathrm{mg} /$ $\mathrm{kg}$ 로 권장하고 있고 $2000 \mathrm{mg} / \mathrm{kg}$ 농도에서 사망하지 않으면 독성이 없다고 판단한다(Chung \& Yu, 2001). 경구독성 시험에 따르면 아롱 부챗말 추출물을 투여한 군에서는 체중변화, 육안적 이상소견은 관 찰되지 않았으며 사망한 동물은 없었다(Table 10). 하지만 $300 \mathrm{mg} /$ $\mathrm{kg}, 2000 \mathrm{mg} / \mathrm{kg}$ 에서 전 례에서 투여 후 2-5 h째에 다뇨(polyuria) 가 관찰되었다. 1 단계 $300 \mathrm{mg} / \mathrm{kg}$ 투여군 2 례에서 투여 후 1 시간 째까지 적색뇨(reddish urine)가 관찰되었고, 1 단계 $2000 \mathrm{mg} / \mathrm{kg}$ 투

Table 9. Cell proliferation in auricular lymph nodes in mice

\begin{tabular}{lcc}
\hline Dose (\%) & BrdU (mean) & SI \\
0 & 0.148 & 1.00 \\
12.5 & 0.129 & 0.87 \\
25 & 0.191 & 1.29 \\
50 & 0.256 & 1.72 \\
HCA 25 & 0.632 & 4.26 \\
\hline
\end{tabular}

Vehicle: DMSO (dimethyl sulfoxide); Positive control: HCA( $\alpha$-Hexylcinnamaldehyde); BrdU: 5-bromo-2'- deoxyurideine.

Vehicle, Padina gymnospora, and HCA were applied to the dorsum of both ears daily for three consecutive days. BrdU was intraperitoneally administered to mice once on day 5. A pair of auricular lymph nodes from each mouse was excised, weighed and stored in a refrigerator until BrdU-enzyme-linked immunosorbent assay was used to measure the level of BrdU incorporation. Evaluation shows that a positive response was defined as the mean stimulation index $(\mathrm{SI})$ of the test group $\geq 1.6$. "+"indicates a positive response; "-" indicates a negative response.

BrdU labeling index $=\left(\right.$ ABS $_{370}-$ ABSblank $\left._{370}\right)-\left(\right.$ ABS $_{492}-$ ABSblank $\left._{492}\right)$

$\mathrm{SI}=$ Mean od BrdU labeling index in test article group

$\mathrm{SI}=\overline{\text { Mean od BrdU labeling index in nagative control group }}$

** Significantly different from the negative control group at $p<0.01$.

Table 10. Mortalities for 15 days in rats administered with $300 \mathrm{mg} / \mathrm{kg}$ (G1 and G2) or 2,000 mg/kg (G3 and G4) of the Padina gymnospora extract

\begin{tabular}{lllllllllll}
\hline $\begin{array}{l}\text { Groups } \\
(\mathrm{mg} / \mathrm{kg})\end{array}$ & $\begin{array}{l}\text { No.Dead/ } \\
\text { No.Dosed }\end{array}$ & 1 & 2 & 3 & 4 & 5 & 6 & 7 & 8 & $9-15$ \\
G1 (300) & $0 / 3$ & 0 & 0 & 0 & 0 & 0 & 0 & 0 & 0 & 0 \\
G2 (300) & $0 / 3$ & 0 & 0 & 0 & 0 & 0 & 0 & 0 & 0 & 0 \\
G3 (2000) & $0 / 3$ & 0 & 0 & 0 & 0 & 0 & 0 & 0 & 0 & 0 \\
G4 (2000) & $0 / 3$ & 0 & 0 & 0 & 0 & 0 & 0 & 0 & 0 & 0 \\
\hline
\end{tabular}

$\mathrm{LD}_{50}$ : median lethal dose.

Table 11. Optical density (OD570) of reconstructed human dermis tissue

\begin{tabular}{|c|c|c|c|c|c|c|}
\hline \multirow{2}{*}{ Test articles } & \multicolumn{3}{|c|}{ Optical density } & \multicolumn{3}{|c|}{ Tissue viability (\%) } \\
\hline & Tissue 1 & Tissue 2 & Tissue 3 & Tissue 1 & Tissue 2 & Tissue 3 \\
\hline DPBS (N.C) & 1.8115 & 1.71 & 72 & 105.4 & 99.5 & 95.2 \\
\hline Aver. & & 1.720 & & & 100 & \\
\hline Padina gymnospora & 1.218 & 1.284 & 1.110 & 70.8 & 74.7 & 64.5 \\
\hline Aver. & & 1.204 & & & 70 & \\
\hline 5\% SDS (P.C) & 0.113 & 0.140 & 0.105 & 6.6 & 8.1 & 6.1 \\
\hline Aver. & & 0.119 & & & 7 & \\
\hline
\end{tabular}

Tissue viabilities of the test article were the values prior to correction for 2,5-diphenyl-2H-tetrazolium bromide (MTT) reduction. 
여군 1 례에서 투여 직후 유연(salivation)이 관찰되었다.

본 시험은 시험물질 아롱부챗말 추출물을 랫드에 독성등급으로 급 성 경구투여시 나타나는 독성을 조사하기 위해 실시되었고 다뇨는 모 든 아롱부챗말 추출물 투여군에서 관찰되어 시험물질에 의한 영향으 로 판단된다. 1 단계 $300 \mathrm{mg} / \mathrm{kg}$ 투여군 2 례에서 투여 후 $1 \mathrm{~h}$ 째까 지 적색뇨(reddish)와 1단계 $2000 \mathrm{mg} / \mathrm{kg}$ 투여군 1 례에서 투여 직 후 유연(salivation)은 투여 직후 일시적으로 관찰된 변화이며, 시험 물질 및 그 대사체에 의한 변화 또는 시험물질의 맛이나 냄새 등 물 리적 성상에 의해 나타난 변화로 판단한다. 시험 결과에 따르면 $\mathrm{LD}_{50}$ (median lethal dose) cut off value는 $2000 \mathrm{mg} / \mathrm{kg}$ 초과였으며, GHS 카테고리는 5 등급 $(2000-5000 \mathrm{mg} / \mathrm{kg})$ 으로 분류할 수 있다.

\section{5. 피부자극 시험: reconstructed human epidermis test}

1 차 피부자극시험은 동물에서 각질세포를 분화유도하여 $3 \mathrm{D}$ 인공 피부모델인 reconstitued human skin quivlaent model (RHE)로 대 체되고 있다(Alépeé et al., 2010; Pedrosa et al., 2017;). OECD guideline TG 439에 따르면 시험물질을 인공조직에 도포 할 때 적어 도 3개를 사용해야 하며 15-60 $\mathrm{min}$ 동안 처치해야 하고 세포 활성 을 측정하기 위해 MTT assay방법으로 흡광도를 측정해 자극성 여 부를 판단하도록 하고 있다(Kim, 2011). MTT 평균 흡광도는 음성 대조군, 아롱부챗말 추출물 군, 양성 대조군 순으로 $1.720,1.204$, 0.119 으로 아롱부챗말 추출물을 도포한 조직에서 생존율이 가장 높 았다(Table 11). 본 시험은 아롱부챗말 추출물을 $\mathrm{RHE}$ 조직에 노출하 였을 때 나타나는 피부자극을 평가하기 위하여 실시하였고, 시험의 타당성 조건을 모두 만족하였다. 본 시험결과에 따르면 아롱부챗말 추출물 처리 조직생존율은 음성대조군에 비해 약 $70 \%$ 였고, 시험물 질이 발색성 및 환원성을 가지므로 보정시험을 실시한 결과, 평균 조 직생존율은 최종 $68.3 \%$ 로 나타나 본 시험물질은 자극성이 없는 물질 로 확인되었다. 따라서 아롱부챗말 추출물은 $\mathrm{RHE}$ 조직에 피부자극 을 나타내지 않는 것으로 판단된다.

\section{Conclusion}

아롱부챗말 추출물의 미백화장품 원료로서 활용하기 위해서 GLP 안전성 시험을 진행하였다. 광감작 시험에서는 아롱부챗말 추출물 을 $10 \%$ 농도로 최대 $72 \mathrm{~h}$ 까지 피부반응을 평가하였고 $0 \%$ 의 광감작 율을 보여 매우 약함으로 평가되었다. 광독성 시험에서는 아롱부챗 말 추출물을 3T3세포에 처리한 후 자외선을 조사한 후 생존율과 광 독성을 평가하였다. 자외선 비조사군과 조사군의 $\mathrm{PIF}$ 및 $\mathrm{MPE}$ 를 확인 한 결과 각각 $1.51,0.006$ 이였으며, 세포 생존율은 자외선 비조사시 94.32-103.23\%, 조사시 4.81-110.18\%으로 광독성을 나타내지 않 은 물질로 판단하였다. 피부감작성을 시험에서는 아롱부챗말 추출물 을 최대 $50 \%$ 용량으로 1 일, 1 회, 3 일간 귀배측에 적용하였다. $50 \%$
투여군에서는 평균자극지수가 1.6 이상으로 감작성이 나타났지만 $25 \%$ 이하 투여군에서는 피부감작성은 보이지 않았다. 경구독성 시험 은 아롱부챗말 추출물을 $300 \mathrm{mg} / \mathrm{kg}$ 를 시작 농도로 하여 독성등급법 으로 투여를 하였으며 그 결과 $\mathrm{LD}_{50}$ cut off value는 $2000 \mathrm{mg} / \mathrm{kg}$ 초 과였으며 GHS 카테고리는 5 등급(>2000-5000 mg/kg)으로 분류되 어 독성이 없는 것으로 확인하였다. 피부자극성 시험은 $\mathrm{RHE}$ 조직 모 델에 아롱부챗말 추출물을 $25 \mathrm{mg}$ 을 도포한 후 MTT를 통해 조직생 존율을 확인하였다. 그 결과 아롱부챗말 추출물 처리군의 평균 조직 생존율은 $68.3 \%$ 으로 피부조직에 자극을 나타내지 않았다. 아롱부챗 말을 이용한 화장품 연구는 미흡한 편이며 이 소재의 독성에 관한 보 고도 거의 이루어지지 않았다. 그러나, Vasantharaja et al., (2019) 의 연구에 따르면 $\mathrm{H}_{2} \mathrm{O}_{2}$ 를 fibroblast 인 L-929 세포에 처치한 뒤 아 롱부챗말 $(25-200 \mu \mathrm{g} / \mathrm{mL})$ 을 처치했을 때 농도의존적으로 세포의 생 존율을 증가시켰다. 따라서 아롱부챗말은 독성을 가지지 않는 비교 적 안전한 물질로 사료된다.

종합하면, 본 연구를 통해 광감작성시험, 광독성시험, 경구 독성시 험. 피부감작성시험, 피부자극성시험에서 아롱부챗말 추출물의 화장 품 원료로서의 안전성을 확인하였다.

\section{Acknowledgements}

본 연구는 부산산업과학혁신원의 지역특화 기술개발, 확산 개 방형연구실 운영사업(B0080509000470)의 일환으로 수행된 결과 입니다. 또한 본 연구는 GLP 인증기관인 (주)켐온에 의뢰하여 진행 하였습니다.

\section{Author's contribution}

K.H.B wrote the manuscript; K.H.B, P.J.A, and K.H.K prepared all samples for the animal replacement tests and analyzed the data; C.Y.S oversaw the project and contributed to all aspects of analysis and experimental design.

\section{Author details}

Hyunbon Kang (doctor course student), Department of Pharmacology, Kyungsung University, 309 Suyeongro, Nam-gu, Busan 48434, Korea; Jia Bak (doctor course student), Department of Pharmacology, Kyungsung University, 309 Suyeong-ro, Nam-gu, Busan 48434, Korea; Hye Kyung Kim (Professor), Department of Pharmacology, Kyungsung University, 309 Suyeong-ro, Nam-gu, Busan 48434, Korea; Yun-Sik Choi (Professor), Department of Pharmacology, Kyungsung University, 309 Suyeong-ro, Nam-gu, Busan 48434, Korea. 


\section{References}

Alépeé N, Tornier C, Robert C, Amsellem C, Roux MH, Doucet $\mathrm{O}$, Pachot J, Méloni M, de Brugerolle de Fraissinette A. A catch-up validation study on reconstructed human epidermis (SkinEthic RHE) for full replacement of the Draize skin irritation test. Toxicol in Vitro, 24: 257-266, 2010.

Baliano AP, Pimentel EF, Buzin AR, Vieira TZ, Romao W, Tose LV, Lenz D, de Andrade TU, Fronza M, Kondratyuk TP, Endringer DC. Brown seaweed Padina gymnospora is a prominent natural wound-care product. Brazilian Journal of Pharmacognosy, 26: 714-719, 2016.

Basketter DA, Gerberick GF, Kimber I, Loveless SE. The local lymph node assay: a viable alternative to currently accepted skin sensitization tests. Food Chemical Toxicology, 34: 985-997, 1996.

Burnett C, Heldreth B, Bergfled WF, Belsito DV, Hill RA, Klassen CD, Liebler DC, Marks JG, Shank RC, Slaga TK, et al. Safety assessment of animal and plant derived amino acids as used in cosmetics. International Journal of Toxicology, 13: 5S-12S, 2014.

Cho JH, Kim JH, Eom SA, Kang MJ, Han YS, Hur MJ. Investigation on the safety of hydroquinone and preservatives among whitening functional cosmetics containing albutin in Korea. Journal of the Society of Cosmetic Scientists of Korea, 45: 399-408, 2019.

Chung YH, Yu IJ. Review of newly adopted OECD acute oral toxicity test guideline 420. Journal of Toxicology and Public Health: an Official Journal of the Korean Society of Toxicology, 17: 195-201, 2001.

Draize $\mathrm{JH}$. Methods for the study of irritation and toxicity of substances applied topically to the skin and mucous membranes. The Journal of Pharmacology and Experimental Therapeutics, 82: 377-390, 1944.

Eibl R, Meier P, Stutz I, Schildberger D, Huhn T, Eibl D. Plant cell culture technology in the cosmetics and food industries: current state and future trends. Applied Microbiology and Biotechnology, 102: 8861-8675, 2018.

Grosjean LD, Sarasin A. The role of UV induced lesions in skin carcinogenesis: an overview of oncogene and tumor suppressor gene modifications in xeroderma pigmentosum skin tumors. Mutation Research, 571: 4356, 2005.
Heo HS, An M, Yoon MS, Park YC. Initial toxicity screening techniques of skin contact materials using glutathione. Asian Journal of Beauty and Cosmetology, 17: 117-127, 2019.

Kim BH, Ahn SH, Choi BD, Kang SJ, Kim YL, Lee HJ, Oh MJ, Jung TS. In vivo evaluation of chondroitin sulfates from Midduk (Styela clava) and Munggae Tuncis (Halocyntha roretzi) as a cosmetic material. Journal of the Korean Society of Food Science and Nutrition, 33: 641-645, 2004.

Kim $\mathrm{BH}$. The introduction of alternative method of reconstructed human skin equivalents for the assessment of skin irritation. Asian Journal of Beauty and Cosmetology, 9: 139-147, 2011.

Kim HK, Bak JA, Kang HB, Kim MJ, Min KS, Park SY, Pyo JS, Choi YS. The skin whitening effects of Padina gymnospora and its active compound, fucosterol. Journal of life science, 30: 598-605, 2020.

Kim HS, Boo SM. Alga flora of Korea Volume 2. Marine brown algae I: heterokontophyta: phaeophyceae: ectocarpales. National Institute of Biological Resources, Incheon, pp4648, 2010.

Kim HW, Shin HJ, Hwang DB, Lee JE, Jeong HG, Kim DG. Functional cosmetic characteristics of Momordica charantia fruit extract. Korean Chemical Engineering Research, 53: 289-294, 2015.

Klaschka U. Naturally toxic: natural substances used in personal care products. Environmental Sciences Europe, 27: 1-13, 2015.

Krasteva G, Georgiev V, Pavlov A. Recent applications of plant cell culture technology in cosmetics and foods. Engineering in life sciences, 21: 68-76, 2021.

Lee EJ, Song KS, Yu $\sqcup$. Characterization of test substance in the GLP. Toxicological Research, 23: 173-177, 2007.

Lee IC, Kim BH, Kim SO, Kim MK. Skin safety evaluation of a Korean traditional prescription, Dansam-samul-tang and Samwhang-sasim-tang. Journal of Physiology \& Pathology, 25: 212-216, 2011.

Lee JK, Park JH, Park SH, Kim HY, Chung ST, Eom JH, Yun SM, Jang EJ, Choi KS, Oh HY. A non-radioisotopic endpoint using bromodeoxyuridine ELISA method for murine local lymph node assay. Toxicological Research, 19: 133-139, 2003.

Lee JK, Sin JS, Kim JH, Eom JH, Kim HS, Park KL. Evaluation 
of phototoxicity for cosmetics and alternative method. Journal of the Society of Cosmetic Scientists of Korea, 31: 245-251, 2005.

Lee WH, Kim NS, Kim B. The application of good laboratory practice (GLP) on in vitro skin irritation test. Journal of Alternatives to Animal Experiments, 10: 23-28, 2016.

Lee YP. Marine algae of Jeju. Academic publishing, Seoul, p95, 2008.

Lin JY, Fisher DE. Melanocyte biology and skin pigmentation. Nature, 445: 843-850, 2007.

Marques CT, Azevedo TC, Nascimento MS, Medeiros VP, Alves LG, Benevides NM, Rocha HA, Leite EL. Sulfated fucans extracted from algae Padina gymnospora have antiinflammatory effect. Brazilian Journal of Pharmacognosy, 22: 115-122, 2012.

Park JY, Lee JY, Lee DY, Kim HD, Kim GS, Lee SE. Melanogenesis inhibitory effect of steamed Platycodon grandiflorum on B16F10 cells. Asian Journal of Beauty and Cosmetology, 17: 37-46, 2019.

Pedrosa TN, Catarino CM, Pennacchi PC, Assis SR, Gimenes F, Consolaro ME, Barros SB, Engler SS. A new reconstructed human epidermis for in vitro skin irritation testing. Toxicology in Vitro, 42: 31-37, 2017.

Rajendran P, Subramani PA, Michael D. Polysaccharides from marine macroalga, Padina gymnospora improve the nonspecific and specific immune responses of Cyprinus carpio and protect it from different pathogens. Fish \& Shellfish Immunology, 58: 220-228, 2016.

Shim JH. Whitening effect of Brazilin in B16F10 Cells. Asian Journal of Beauty and Cosmetology, 17: 287-294, 2019.

Silva TMA, Alves LG, Queiroz KCS, Santos MGL, Marques CT,
Chavante SF, Rocha HAO, Leite EL. Partial characterization and anticoagulant activity of a heterofucan from the brown seaweed Padina gymnospora. Brazilian Journal of Medical and Biological Research, 38: 523-533, 2005.

Spielmann H, Balls M, Dupuis J, Pape WJ, Silva O De, Holzhutter HG, Gerberick, Liebsh M, Lovell WW, Pfannenbecker U. A study on UV filter chemicals from annex VII of European union directive 76/768/EEC, in the in vitro 3T3 NRU phototoxicity test. Alternatives to Laboratory Animals, 26: 679-708, 1998.

Spielmann H, Balls M, Dupuis J, Pape WJ, Silva O De, Holzhutter HG, Gerberick, Liebsh M, Lovell WW, Maurer T, Pfannenbecker U, et al. The international EU/COLIPA in vitro phototoxicity validation study: result of phase II (Blind trial). Part 1: The 3T3 NRU phototoxicity test. Toxicology in vitro, 12: 305-27, 1998.

Trehan S, Michniak-Kohn B, Ben K. Plant stem cells in cosmetics: current trends and future directions. Future Science OA, 3: FSO226, 2017.

Vasantharaja R, Abraham LS, Gopinath V, Hariharan D, Smita KM. Attenuation of oxidative stress induced mitochondrial dysfunction and cytotoxicity in fibroblast cells by sulfated polysaccharide from Padina gymnospora. International Journal of Biological Macromolecules, 124: 50-59, 2019.

Wiemann C, Berthold K, Heusener A, Krüger N, Seeberger A, Stropp G. Joint positive control testing in guinea pig skin sensitization test. A harmonized approach. Regulatory toxicology pharmacology, 35: 14-22, 2001.

Yu $\sqcup$, Lee JY. Introduction of GLP system into occupational toxicology research. Journal of Korean Society of Occupational and Environmental Hygiene, 12: 1-6, 2002. 


\section{국문초록}

\section{화장품 원료로 사용하기 위한 아롱부챗말 에탄올 추출물의 안전성 연구}

강현본 ${ }^{1}$, 박지아 ${ }^{1}$, 김혜경 ${ }^{1}$, 최윤식 ${ }^{1,23^{*}}$

${ }^{1}$ 경성대학교 약학과, 부산, 한국

${ }^{2}$ 경성대학교 화장품학과, 부산, 한국

${ }^{3}$ 경성대학교 스마트헬스케어 융복합연구센터, 부산, 한국

목적: 이전의 연구에서 우리는 아롱부챗말 에탄올 추출물의 미백효능을 확인하였다. 본 연구는 동물대체시험법을 통해 아롱부챗말 추출물의 안전성을 확인하였다. 방법: 아롱부챗말 추출물의 안전성을 확인하기 위하여 광감작성시험(Harber 시험), 시험관 내 3T3 $\mathrm{NRU}$ 광독성시험, 국소림프절시험, 급성경구독성시험 그리고 인체피부모델을 이용한 피부자극시험을 진행하였다. 모든 시험은 식 품의약품안전처의 표준지침에 따라 GLP인증 기관인 (주켐온에 의뢰하여 진행되었다. 결과: 아롱부챗말 추출물은 $0 \%$ 의 광감작율로 광감작성을 보이지 않았다. 시험관 내 $3 \mathrm{~T} 3 \mathrm{NRU}$ 광독성시험에서는 상대생존율이 기준치 이상으로 나타나 광독성 물질이 아닌 것으 로 판명되었다. 인체피부모델을 이용한 피부자극시험에서는 피부자극성을 보이지 않았으며 국소림프절시험에서도 피부감작성을 보이지 않았다. 마지막으로 아롱부챗말 추출물을 흰쥐에 경구투여 한 결과 매우 안전한 물질로 나타났으며 LD50 값은 $2000 \mathrm{mg} / \mathrm{kg}$ 이상으로 측정되었다. 결론: 아롱부챗말 에탄올 추출물은 피부에 적용할 때 안전한 것으로 증명되었으며 본 연구진의 이전 효능 연 구 결과를 고려할 때 화장품 소재로 매우 가치가 있는 것으로 추정된다.

핵심어: 동물대체시험, 화장품 소재, 아롱부챗말, 안전성, 해조류

본 연구는 부산산업과학혁신원의 지역특화 기술개발, 확산 개방형연구실 운영사업(B0080509000470)의 일환으로 수행된 결과입 니다. 또한 본 연구는 GLP 인증기관인 (주)켐온에 의뢰하여 진행하였습니다.

\section{참고문헌}

김배환, 안삼환, 최병대, 강석중, 김영림, 이후장, 오명주, 정태성. In vivo에 의한 미색류 콘드로이틴황산의 기능성 화장 품 소재로서의 가능성. 한국식품영양과학회지, 33: $641-645,2004$.

김배환. 인공피부를 이용한 피부자극 대체시험법 소개. 아시안뷰티화장품학술지, 9: 139-147, 2011.

김현우, 신혜진, 황단비, 이지은, 정향리, 김동욱. 여주 열매 추출물의 기능성화장품 소재 특성. 한국화학공학회지, 53 : 289-294, 2015.

김혜경, 박지아, 강현본, 김민지, 김지민, 민경성, 박성연, 표재성, 최윤식. 아롱부챗말과 그의 활성성분인 fucosterol의 미 백효과. 생명과학회지, 30: 598-605, 2020.

박정용, 이지연, 이대영, 김형돈, 김금숙, 이승은, 서경혜. B16F10 세포에서 증숙도라지 추출물의 멜라닌 생성 억제 효과. 아시안뷰티화장품학술지, 17: 37-46, 2019.

심중현. B16F10 세포에서 브라질린의 미백 효능. 아시안뷰티화장품학술지, 17: 287-294,2019

이용필. 제주의 바닷말. 아카데미서적, 서울, $\mathrm{p} 95,2008$.

이원희, 김남수, 김보라. 인체피부모델을 이용한 피부자극시험법의 비임상관리기준 적용. 한국동물시험대체법학지, 10 :

23-28, 2016.

유일재, 이준연. 산업독성연구에서의 GLP (Good Laoratory Practice) system 도입의 필요성. 한국산업위생학회지, 12:

$1-6,2002$.

이은정, 송경석, 유일재. GLP 시험에서의 시험물질 특성파악. 한국독성학회지, 23: 173-177, 2007. 
이인철, 김배환, 김성욱, 김미경. 한방 처방제인 단사사물탕과 삼황사심탕의 피부적용제로의 활용을 위한 피부 안전성 평 가 연구. 동의생리병리학회지, 25: 212-216, 2011.

이종권, 신지순, 김진호, 엄준호, 김형수, 박귀례. 화장품 광독성 평가와 동물대체시험법. 대한화장품학회지, $31: 245-$ $251,2005$.

이종권, 박재현, 박승희, 김형수, 정승태, 엄준호, 윤소미, 장은정, 최광식, 오혜영. BrdU ELISA를 이용한 국소 림프절 시 험법의 비방사선법 연구. 한국독성학회지, 19: 133-139, 2003.

정용현, 유일재. OECD test guideline 420 고정용량 급성경구독성시험법에 대한 고찰. 한국독성학회지, 17: 195-201, 2001.

조중희, 김지형, 엄선아, 강민정, 한영선, 허명제. 국내 유통 알부틴 함유 미백 기능성화장품 중 히드로퀴논 및 살균보존제 안전성 조사. 대한화장품학회지, 45: 399-408, 2019.

허혜선, 안민지, 윤미숙, 박영철. 글루타치온을 이용한 피부접촉물질에 초기 독성 탐색 기술. 아시안뷰티화장품학술지, 17: 117-127, 2019. 


\section{中文摘要}

\section{大団扇藻乙醇提取物作为化妆品成分的安全性评估}

姜賢本 ${ }^{1}$, 朴智雅 $^{1}$, 金惠京 $^{1}$, 崔允植 $^{1,2,3 *}$

京城大学药学科, 釜山市, 韩国

2京城大学化妆品学科, 釜山市, 韩国

3京城大学智慧医疗融合研究中心，釜山市，韩国

目的: 在之前的一项研究中, 我们确定了大团扇藻乙醇提取物的皮肤美白作用。本研究通过动物替代试验确认提 取物的安全性。方法: 为评价大団扇藻取物的安全性, 进行了光敏试验（Harber 试验）、体外 3T3 中性红吸收

（3T3 NRU）光毒性试验、局部淋巴结试验（5-溴-2'-脱氧尿苷酶联免疫吸附试验）、急性口服毒性试验和重建 人表皮 (RHE) 试验。所有实验均遵循韩国食品药品安全部的指导方针, 并由 GLP 认证组织 (Chemon Inc.) 进 行。结果: 大団扇藻提取物显示无光敏作用 : 检测到0\%光敏（I级：非常弱）。在3T3 NRU光毒性试验中, 提取 物处理的细胞的相对活力高于指导水平 ; 因此，该提取物被归类为无光毒性。在 RHE 测试模型中，用提取物处 理不会引发皮肤刺激，在局部淋巴结检测中不会引起皮肤过敏。最后，该提取物对大鼠的口服给药表明它不是 一种有害物质，因为 LD50 估计为 $>2,000 \mathrm{mg} / \mathrm{kg}$ 。结论: 裸孢子虫的乙醇提取物被证明用于皮肤时是安全的。 结合我们之前对其功效的研究，我们得出结论，该提取物具有用作化妆品成分的潜力。

关键词: 动物替代试验, 化妆品成分, 大団扇藻, 安全, 海藻 